\title{
On the telencephalon of Narke japonica Temminck et Schlegel.
}

\author{
By \\ Seinin Terui and Juh Shen Shyu. \\ Department of Anatomy, Mancbsria Medical College, Muleden, Mancboukeso \\ (Director: Prof. N. Suzuki). \\ With 14 textfigures
}

I. Introduction.

The brain of Narke japonica has been treated by N. Suzuki (1936), especially on the lobus electricus and nervi electrici. As for the electric organ of fishes, it has been described by Borschert (i903), Fritsch (1892, 93), Mencl (1901), Reihenheim (1897) in Torpedo marmorata and also by Stuart and Kamp (1934) in Malopterurus electricus. The other brain part of Narke japonica, however, remains as it was. Besides, the cytoarchitectonic structure of the telencephalon in this specimen rather approximates to that of Hyroterata (such as Myxine glutinosa) than that of Batoidei (for example Torpedo marmorata). In this paper, therefore, it is first dealt with the hemispheres of Narke japonica.

\section{Material and methods.}

All of the serial microscopic preparations were made in the frontal and horizontal sections, and stained after Weigert-Pal, Weigert-Pal-Vitalscharlach VIII, Nissl and Bielschowsky. These materials have been mostly indebted to Prof. Dr. K. Kudo to whom we wish to take this opportunity of heartily thanking.

\section{Abbreviations for all figures.}

a. prec. sup. inf. ..............area precommissuralis superior et inferior.

a. olf. med. area olfactorius medialis.

a. sup. bas. area superficialis basalis. 
com. ant. p. v. ...............commissura anterior pars ventralis.

la. I-la. s ...................lamination first-lamination fifth.

lat. olf. rad. ...................lateral olfactory radiation.

med. olf. rad. .................medial olfactory radiation.

nuc. preop. ...................nucleus preopticus.

nuc. olf. lat. ..................nucleus olfactorius lateralis.

nuc. med. sep. ................nucleus medialis septi.

p. d. com. ant. ................pars dorsalis commissurae anterioris.

pal. lob. ........................pallial lobe.

pr. hip. primordium hippocampi.

som. area somatic area of Johnston.

s. bas. ant. sulcus basalis anterior.

s. d. med. sulcus dorsomedialis.

s. v. med. sulcus ventromedialis.

str. striatum.

tr. str. th. hypoth. tractus strio-thalamicus et hypothalamicus.

tr. tae. tractus taeniae.

tx. pal. tractus palli of Edinger.

tr. olf. hab. tractus olfacto-habenularis.

v. imp. ventriculus impar.

\section{Explanation on the diagram of the frontal sections of the brain.}

A. On the nuclear masses of the telencephalon of Narke japonica.

The rostral segment of the massive and compact telencephalon is composed of two lateral lobes having the intermediated cell zone between them. The lateral and rostral end of lobe is occupied with the medial olfactory area or nucleus olfactorius medialis. More caudally, this area is surrounded by the narrow zone of the scattered cells which take up the anterior extension of the pallial and subpallial lobes.

Figures I to 14. A series of frontal sections through the brain of Narke japonica, arranged from rostral to caudal.

Figure I. Section roo. The dorsomedial sulcus is not so deep as that of the ventromedial one. The sulcus basalis anterior can feebly be observed at the ventrolateral corner of the rostral brain part. The cellular demarcation of this section is somewhat obvious and the ventriculus lateralis, recessus dorsalis and the recessus neuroporicus are quite absent contrary to those of the other selachian classes as shown by Johnston, Holmgren, Kuhlenbeck and others. The area olfactorius medialis is bordered dorsomedially by the rostral 


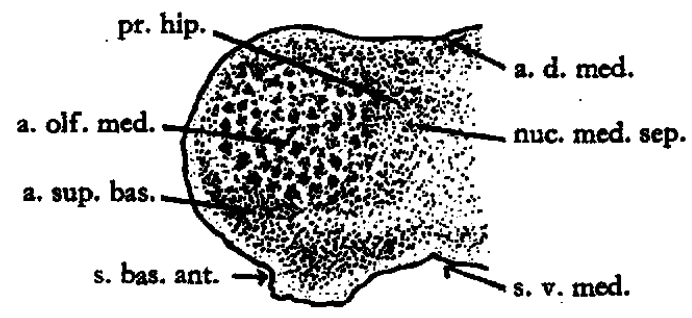

Fig. 1.

portion of the primordium hippocampi with the somewhat dense cell group and medially by the anterior part of the nucleus medialis septi. Ventral to the medial olfactory area, there is seen the anterior portion of the area superficialis basalis (cortex olfactoria of Edinger, nucleus taeniae of Ariëns Kappers).

Figure 2. Section 176. The dorsomedial sulcus becomes deeper. The medial olfactory area slightly moves dorsomedialward decreasing its area. Dorsal to this area, the anterior pallial layer separates from its fellow of the opposite side according to the dorsal enlargement of the united cell

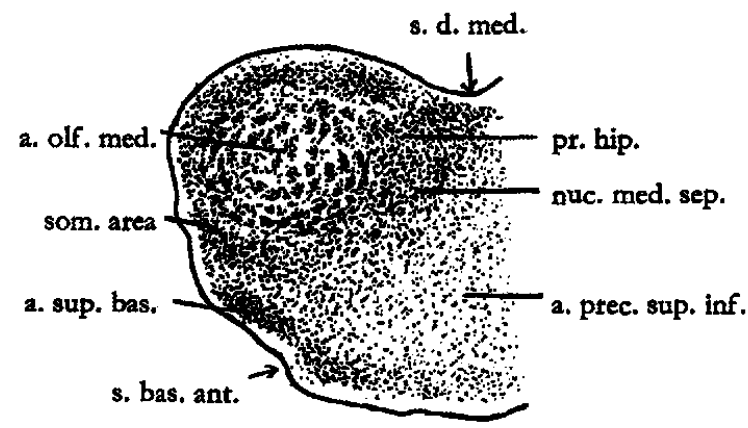

Fig. 2.

group of the primordium hippocampi and the nucleus medialis septi. Ventrolateral to the medial olfactory area, the somatic area of Johnston comes in sight as a poor cell group. The area superficialis basalis (or tuberculus olfactorius of Dart, and of Herrick, Hypostriatum Catoi, or nucleus postolfactorius of Houser) lies as it stands, while the primordium hippocampi elongates dorsoventral in direction along the medial sphere of the medial olfactory area. The nucleus medialis septi of each lobe is separated from its fellow of the opposite side by the dorsomedial septal structure of the cell scanty zone. The fused body of scattered cells of the area precommissuralis superior et inferior of Johnston chiefly occupies the telencephalon medium.

Figure 3. Section 232. The medial olfactory area is scarcely visible. The primordium hippocampi and the nucleus medialis septi are still standing. 


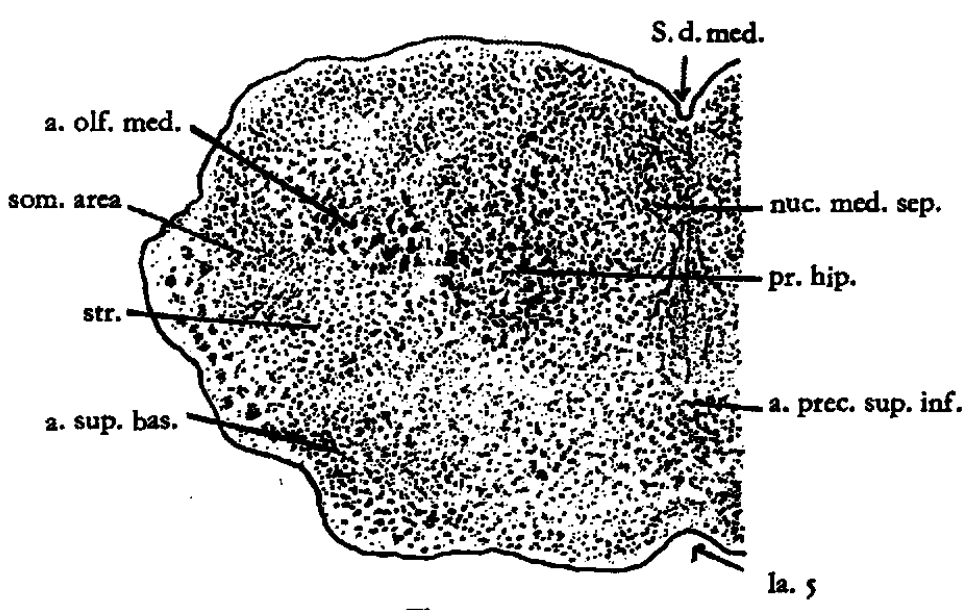

Fig. 3 .

Medioventral to the somatic area of Johnston begins to appear the anterior portion of the striatum. In this section, the olfactory stalk is situated as the lateral projection of the lobe and the lateral olfactory area or the nucleus olfactorius lateralis holds the ventrolateral wall of the brain. The area superficialis basalis is somewhat diffusely arranged with cells. The area precommissuralis slightly enlarges its area. The dorsolateral pallial lobe shows the irregular laminar structure of four layers.

Figure 4. Section 270. The septal structure of the dorsal half disappears and is replaced by the dorsomedial extension of the primordium hippocampi which elongates dorsoventral in direction is wholly enveloped by the cell scanty zone. The pallial lobe indicates the laminal structure of five

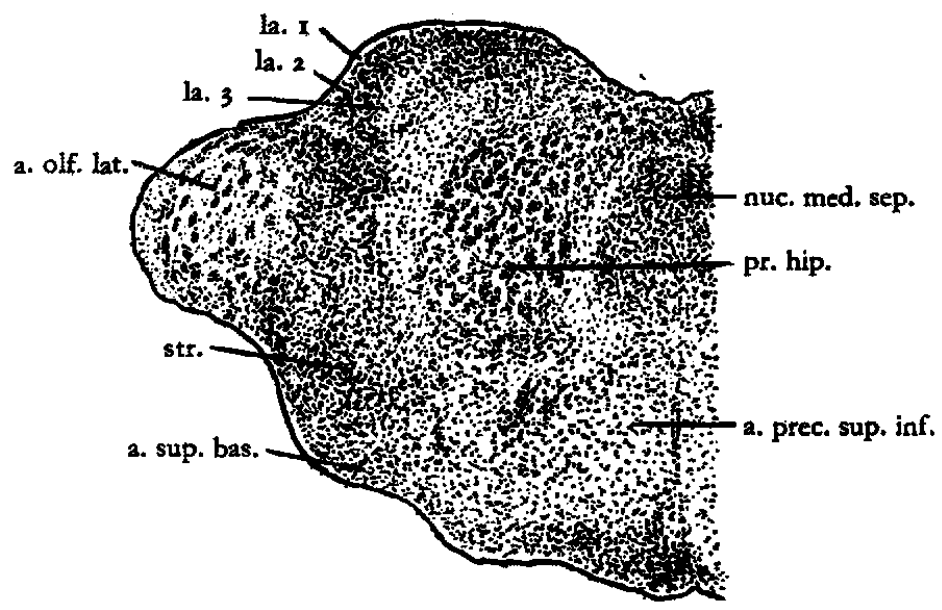

Fig. 4- 
layers as shown by Jansen in Myxine glutinosa. Ventral to the somatic area of Johnston which quite reduces its area, the striatum becomes larger. The area precommissuralis superior et inferior cannot be clearly divided in its cell arrangement. Ventral to the latter area, the area superficialis basalis retains as it was. The lateral olfactory area or the nucleus olfactorius lateralis makes the ventrolateral wall of the telencephalon.

Figure 5. Section 280. The nucleus medialis septi reduces its area and unites with its fellow of the opposite side into single ovoid shape on the midline. This body is superficially surrounded by the cell scanty zone and moreover, the whole body is bordered with the dorsomedial area of the

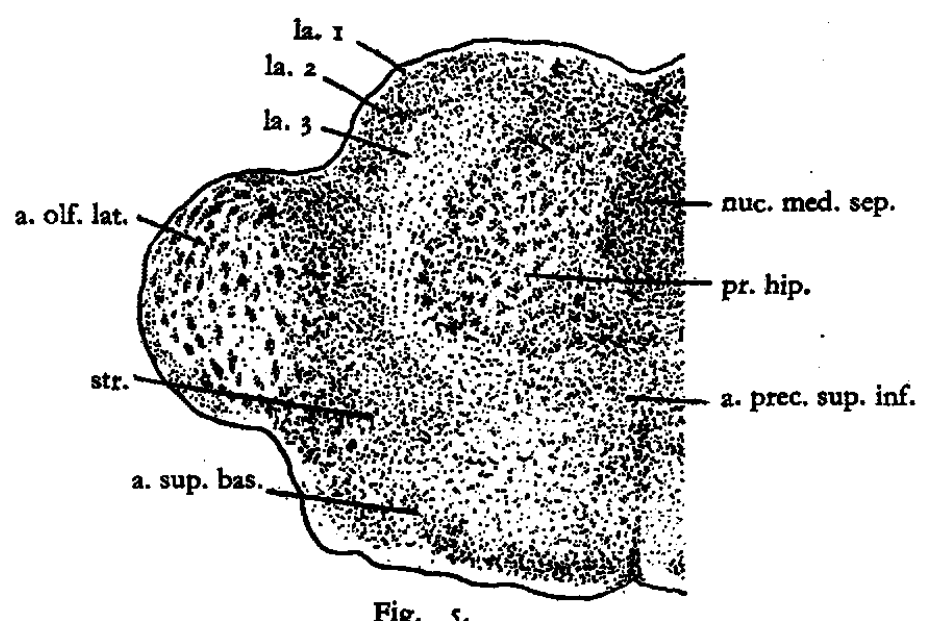

Fig. s.

primordium hippocampi. Furthermore the latter projects ventromedially to fuse with the contralateral component. The deepest layer of the pallial lobe has a relatively larget area and elongates ventromedially along the ventral sphere of the primordium hippocampi. Continuously to the latter portion, the cell scanty layer acrosses the midline and separates the single body of the nucleus medialis septi and the area precommissuralis superior above and below. This may be corresponded with the zona limitans medialis. The striatum increases its area comparing with that of the former described above. Lateral to the striatum lies the somatic area and continues to the caudoventral extension of the pallial layer being bordered ventrolaterally by the area olfactorius lateralis and ventrally by the dorsolateral extension of the tuberculus olfactorius. The area superficialis basalis is somewhat decreased in its area by the enlargement of the lateral olfactory area.

Figure 6. Section 438 . The pallial lobe is highly developed covering the dorsal roof of the telencephalon, so that its four layers across the dorsal 


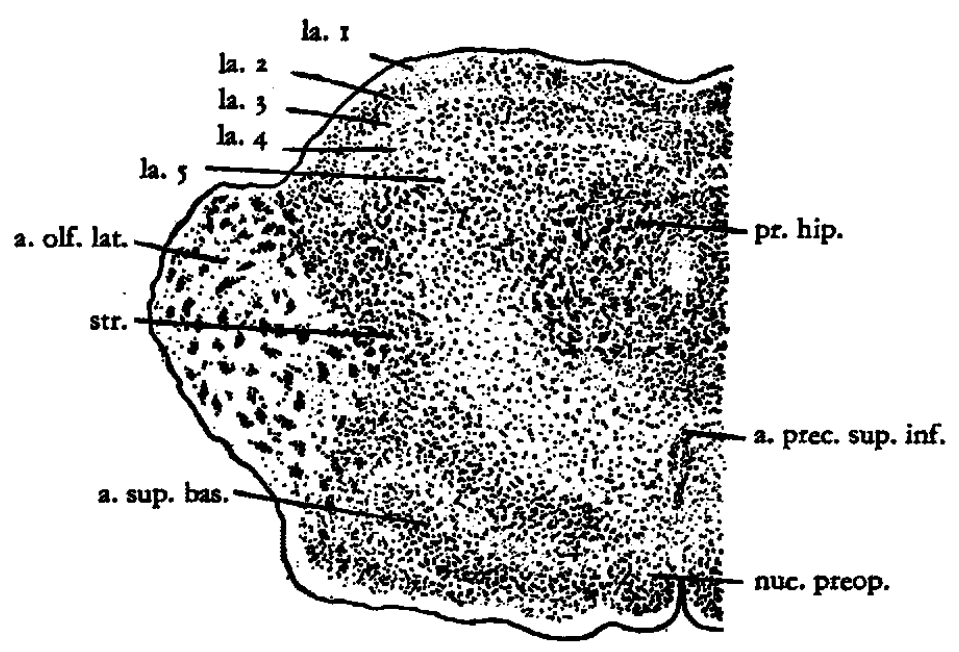

Fig. 6.

midline and the fifth layer enlarges mediocentrally. The primordium hippocampi, therefore, reduces its area and unites with its fellow of the opposite side in the middle beneath the dorsal pallial layer. The nucleus medialis septi is quite out of sight being replaced by the united body of the primordium hippocampi. The somatic area passes caudalward with the somewhat reduced cell group. The lateral olfactory area gradually enlarges and makes the thick wall of the ventrolateral portion of the brain and moreover the ventral extension of this part elongates ventromedially toward the lower of the area superficialis basalis. The area precommissuralis retains as it was. At the ventromedial region of the telencephalon, the anterior segment of the nucleus preopticus begins to appear as a round cell group.

Figure 7. Section 522 . The dorsal roof of the telencephalon is occupied by the thick laminar four layers of the pallium and dorsolateral pallial lobe indicates the five layers as shown in the former section described above. But the fusion of the fifth layer of the pallium and the primordium hippocampi occurs in this section. The posterior segment of the primordium hippocampi is scarcely observed and is separated again into two components. The striatum increases its area as the semiovoid shape in section. The lateral olfactory area is gradually decreased in its size. The nucleus preopticus fuses with its fellow of the opposite side at the ventral midline and the area superficialis basalis indicates the laminar structure. The nucleus precommissuralis is markedly reduced in its area. The telencephalon medium in this section is separated by the feeble slit of the ventriculus impar into the precommissural area and the cell group of the nucleus preopticus. 


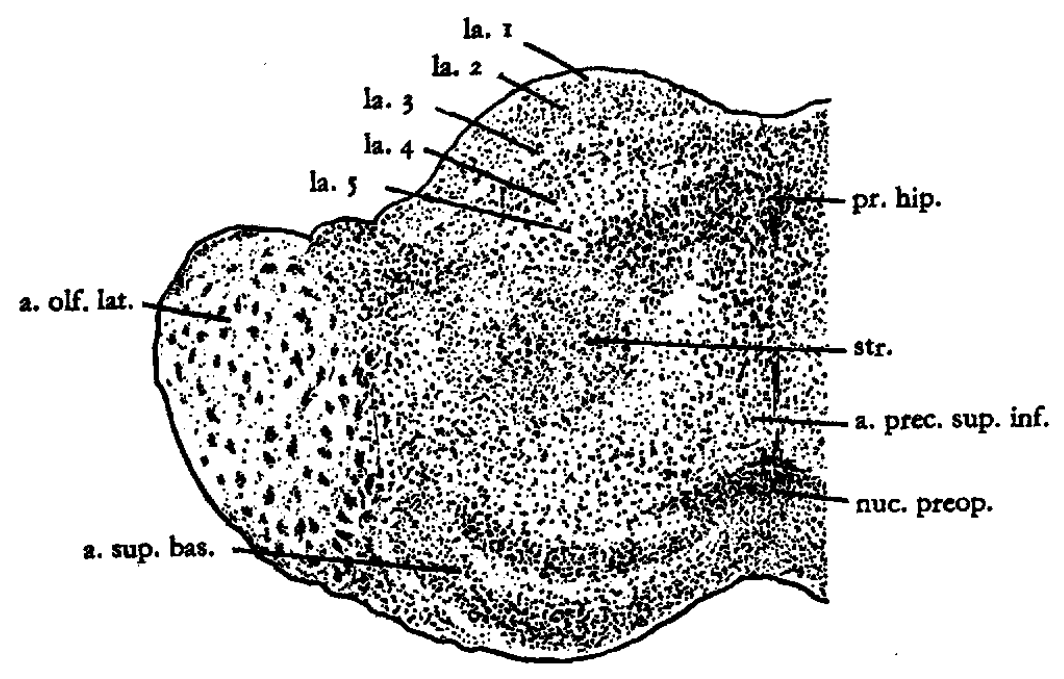

Fig. 7.

Figure 8. Section 544. Both the second pallial layer formerly met at the midline part again right and left. Each of them makes the dorsolateral thickening of cells. The fourth pallial layer however, acrosses the

la. I

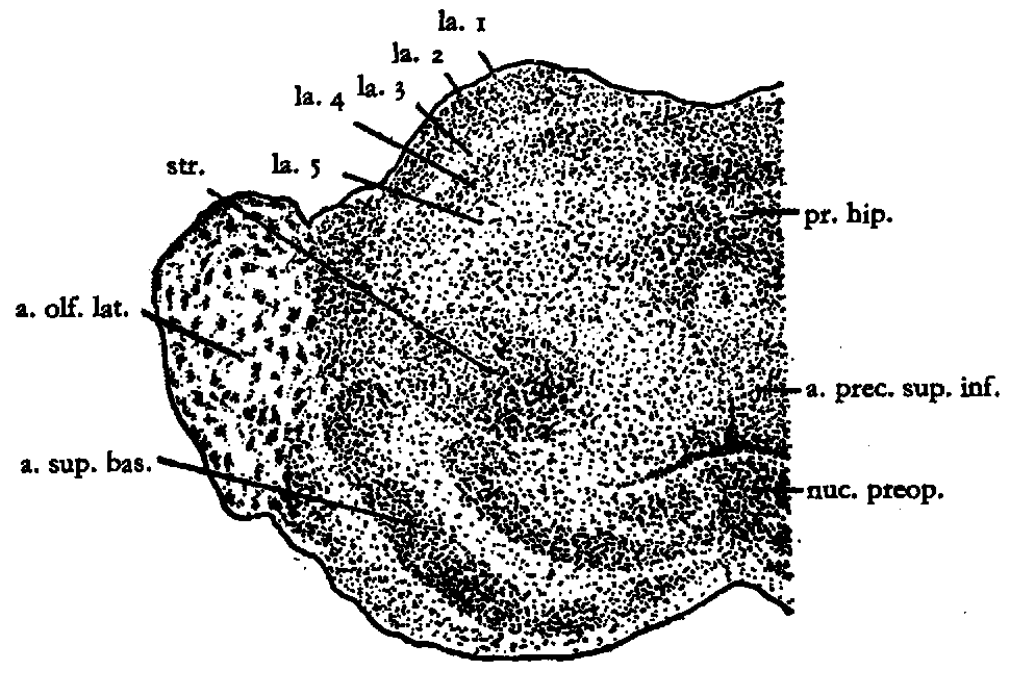

Fig. 8.

midline connecting with its fellow of the opposite side and covers the dorsal surface of the primordium hippocampi. Lateral to the latter portion the fifth pallial layer is present with the somewhat larger area. The primordium hippocampi decreases its area and contacts with the contralateral component 
having the central septal structure between them ventrolateral to the primordium hippocampi, where lies the striatum as a round cell group being bordered medially by the precommissural area. The lateral olfactory area gradually reduces its area but ventromedially it elongates as a cell scanty band covering the base of the area superficialis basalis. The area superficialis basalis is retained with the laminar layer as shown above. The cell group which may be derived from the nucleus preopticus stretches medially under the transversal linear slit of the ventriculus impar.

Figure 9. Section 568 . The thickness of the pallial lobe varies in each layer, so that its second layer of the dorsomedial part is quite absent and the dorsolateral portion is reduced in thickness. The third layer slowly curves

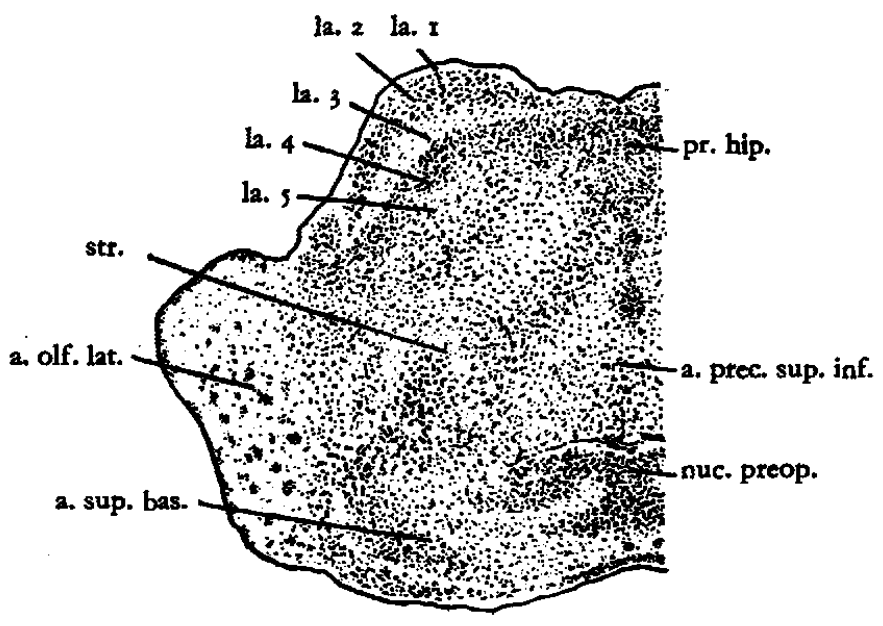

Fig. 9.

as the convexed semicitcular cellular bridge. The fifth layer and the primordium hippocampi are generally decreased in its area. Ventrolateral to the latter part, the striatum enlarges its area. The area precommissuralis becomes narrower. The area superficialis basalis shows a typical laminar structure. The basal extension of the lateral olfactory area reaches the ventral midline along beneath the area superficialis basalis. The lateral olfactory area gradually reduces its area.

Figure ro. Section 598. The pallial lobe is less in width but larger in height, so that the first layer remains only at the dorsolateral sphere, while the third layer is remarkable in thickness and the fifth layer is shrunk. The septal structure is somewhat broad occupying the dorsal half in midline. The primordium hippocampi is pressed basally in the telencephalon medium by the interposition of both nuclei of the striatum. The lateral olfactory area is 
la. $x$

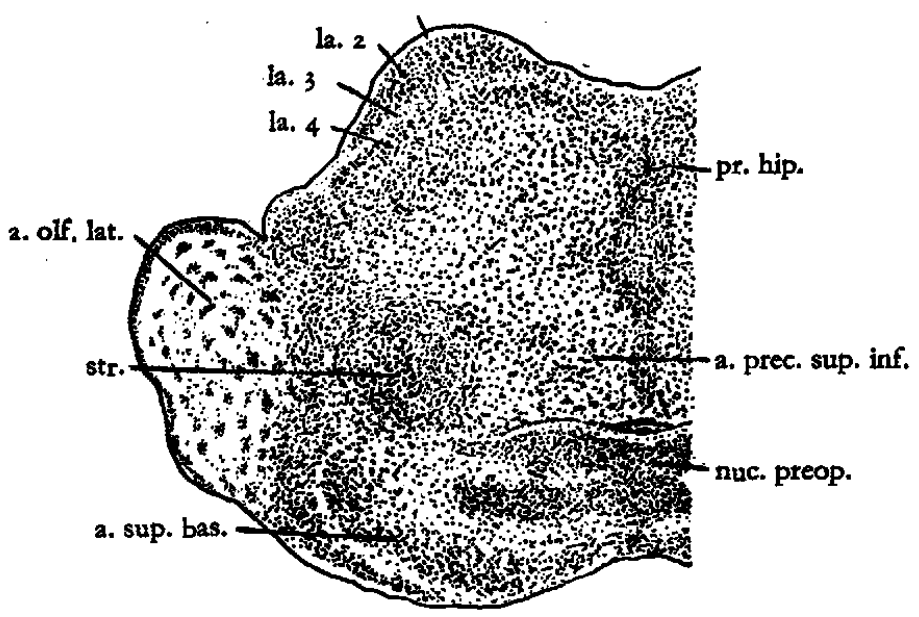

Fig. Io.

gradually reduced in its area. The somatic area elongates ventromedially along the ventral surface of the brain. The area superficialis basalis also indicates a typical laminar structure. The cell arrangement of the nucleus preopticus is seen as the wing of dragonfly in section beneath the anterior slit of the ventriculus impar.

Figure Ir. Section 654. The dorsal half area is mostly occupied with the cells of the third layer of the pallium. The primordium hippocampi is scarcely visible. The caudal segment of the striatum is situated at the dorsolateral margin of the lateral extension of the ventriculus impar. The telencephalon

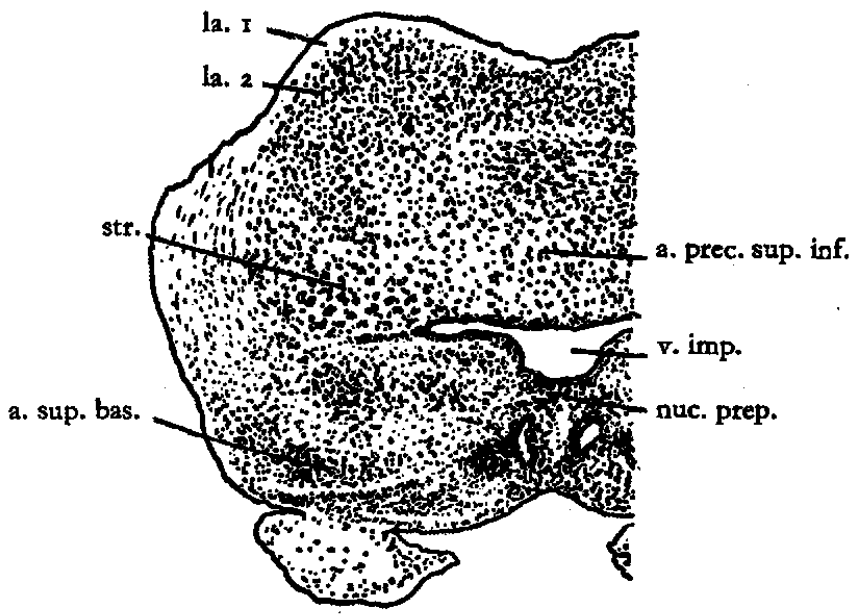

Fig. 11 . 
medium is very shallow, so that the area superficialis basalis is scattered with cells. The nucleus preopticus has the relatively large cell arrangement. Lateral to the latter nucleus there is a small cell group. The ventriculus impar invaginates at the midline with a relatively wide fissure. The area precommissuralis is quite absent.

Figure 12. Section 676. The telencephalon medium remarkably reduces. The ventricle gradually enlarges, so that the median fissure somewhat deeply and widely invaginates. The anterior segment of the plexus chorioideus

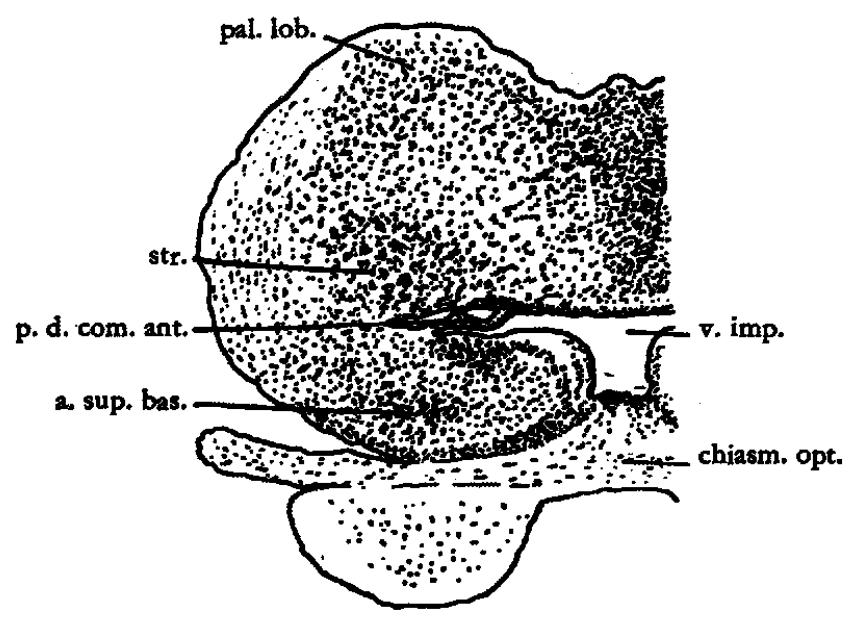

Fig. 12.

is seen at the lateral comer of the ventricle. In this section, the chiasma opticum appears and separates the brain part into the anterior segments to the thalamencephalon and the lobus inferior above and below.

In the segment, the area superficialis basalis is scarcely visible at the ventrolateral corner of the brain. This area is quite reduced in its area and is situated at the dorsolateral angle of the lateral extension of the ventricle.

B. Fiber connections of the telencephalon.

The medullated fibers derived from the medial olfactory radiation apparently terminate in the anterodorsal portion of the primordium hippocampi and the pallial lobe. The other pierce of this radiation stream superficially along the dorsal and rostral part of the telencephalon. These fibers meet with the contralateral component uncrossed at the dorsal septal part of the brain. Extending back this fascicle prolongates caudoventrally through the precommissural area to the preoptic region. A little number of fibers leave this region to enter the medial portion of the area superficialis basalis 
as has been suggested by Johnston. In the horizontal series, this fiber connection is surely visible.

The majority of the lateral olfactory radiation richly interpret the lateral olfactory area but the entire spreading of the medullated fibers of this radiation in the telencephalon cannot be assumed in this specimen. The medial olfactory area appears just in the central part of the forebrain, the fibers derived from the striatum stream ventromedially to make up the tractus striothalamicus et hypothalamicus. Further caudally this fascicle intermingles the fibers of the tractus olfactorius lateralis. Extending further back the fibers which connect the lateral olfactory area of the two sides cross the dorsal part of the primordium hippocampi. It may be the pars dorsalis commissurae anterioris or the decussatio interhemispherica as described by Ariëns Kappers in Galeus canis, and it terminates in the epistriatum (Fig. 13). In this level there are seen the fibers which arise from the whole area of the pallial lobe and swing centripetally to the septal portion passing through the ventral half of the primordium hippocampi. These fibers intersect with the fibers of the pars dorsalis commissurae anterioris on its way. It may be the

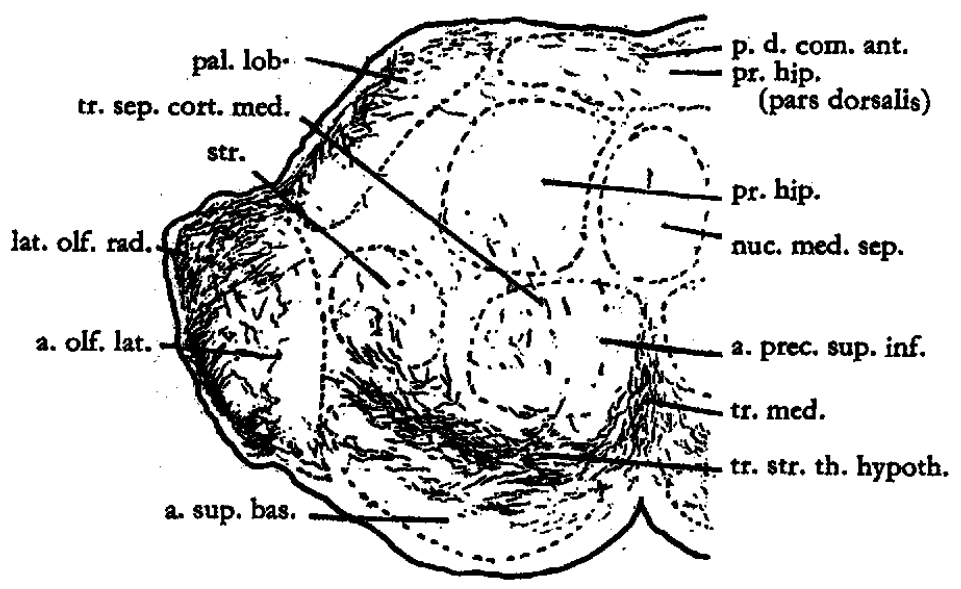

Fig. 13.

tractus septocorticalis as shown by Ariëns Kappers or tractus olfactorius septi by Johnston.

The fibers of the tractus strio-hypothalamicus chiefly arise from the striatum and prolongate caudalward throughout the total length of the area superficialis basalis being added with the lateral olfactory area by the olfacto-somatic correlation tract of Johnston. The former three portions are also related with the pallial lobe by the diffused fibers. The most part of the fibers derived from the lateral olfactory area and the area superficialis 
basalis swing ventromedially above the tractus strio-hypothalamicus and extend back making up the commissura anterior pars ventralis.

On the level where both the pallial lobes continue to each other at the dorsomedial portion, the fibers from one side to the opposite side can be observed being intermingled with the fibers of the decussatio interhemispherica. The fibers of the tractus palli of Edinger from the caudal end of hypothalamus go up the dorsolateral border of the telencephalon with the loose and very few fibers (Fig. 14). At the lateral end of the transversal slit of the ventriculus

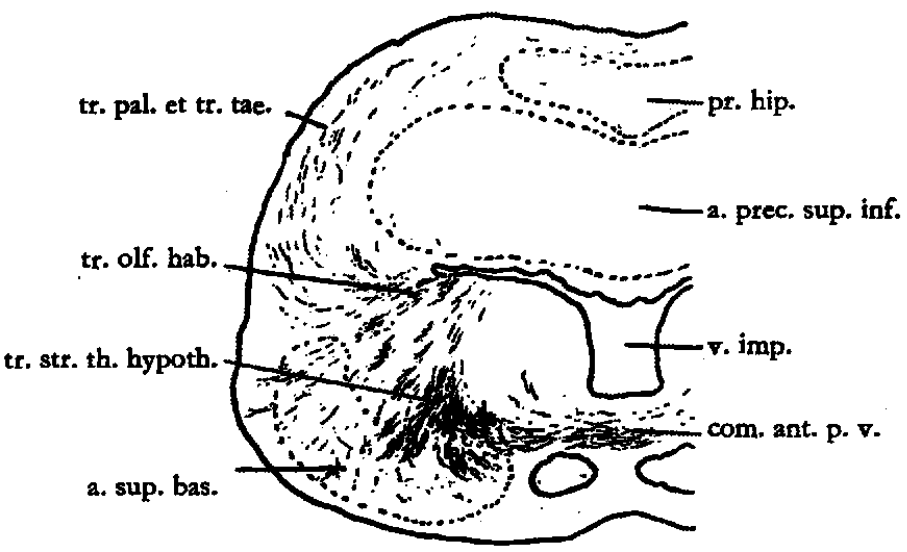

Fig. 14.

impar, the fibers of the tractus taeniae dorsalis swing ventromedially along the medial zone of the fascicle just described above. In this level, the fibers of the tractus olfacto-habenularis curve medially along the lateral zone of the tractus taeniae. Adding to this fascicle, the fibers join from the area superficialis basalis and make up the stria medullaris extending back in the epithalamus. Few fibers of the tractus olfactomedialis or the tractus septohabenularis also join these fascicles. All of the bundles are myelinated and they interpret the lateral habenular nucleus of the cell scanty portion.

\section{Summary of the hemispheres of Narke japonica.}

The forebrain represents a massive body, so that the recessus neuroporicus, the recessus olfactorius bulbaris, recessus ventricularis, recessus dorsalis et lateralis cannot be observed in this specimen. In the anterior segment of the whole forebrain, the dorsomedial sulcus is not so deep as that of the ventromedial. The sulcus basalis anterior is feebly visible at the ventrolateral 
angle of the brain and extends back the total length of the forebrain. The lateral expansion of the fila olfactoria is remarkably observed, so that the area olfactorius lateralis is relatively well developed making a lateral wall.

\section{The area olfactorius medialis et lateralis.}

The area olfactorius medialis chiefly occupies the rostral and lateral end of the lateral olfactory lobe and extends caudolateralward to connect with the dorsoanterior portion of the area olfactorius lateralis being gradually reduced its volume. The dorsal sphere of this area is throughly distributed with the pallial lobe which shows a laminar layer, and the basal by the spherical lobe. The area olfactorius lateralis occupies the ventrolateral wall of the forebrain. The ventral extension of this area elongates ventromedially along the basal zone of the brain covering the lateral part of the tuberculus olfactorius.

\section{The pallial lobe.}

The pallial lobe makes the dorsal roof of the forebrain stretching caudally almost the total length of the hemisphere. It shows a cortical laminar layer, so that the rostral segment is composed of two layers being separated from each other by the dorsal expansion of the primordium hippocampi. Extending back it gradually increases its thickness and numbers of the laminar structure according with the decrease of the area olfactorius medialis: such as the superficial noncellular zone (the first layer), the medium sized cell lamina (the second layer), the cell scanty zone (the third layer), the somewhat smaller cell lamina (the fourth layer) and the deepest cell scanty zone (the fifth layer) as shown by Jansen in Myxine gultinosa.

\section{The primordium bippocampi.}

At the rostral segment, this area is limited with triangular section bordering the dorsomedial sphere of the area olfactorius medialis. It gradually extends back and swells ventrally with the decrease of the area olfactorius medialis. At the middle segment, the dorsomedial extension unites with its fellow of the opposite side beneath the fused laminar layer of the pallial lobe. On the level where the area olfactorius medialis disappears, the ventral expansion of the primordium hippocampi occupies nearly the central part of the hemisphere being bordered medially by the area precommissuralis, laterally by the fifth laminar layer of the pallial lobe. It finally extends caudalward almost the total length of the area olfactorius medialis. 


\section{The nucleus medialis septi.}

In the rostral segment of the forebrain, there is no septal structure so that the medium-sized cells are diffusively arranged. More caudally on the level where the septal structure begins to appear, the nucleus medialis septi lies medial to the anterior segment of the primordium hippocampi as an ovoidal shape in section having the cell scanty septum between both of the nucleus medialis septi. Caudally it gradually reduces its area and finally fuses with the contralateral component into a single body without the septum. Most part of the caudal segment of this body is almost surrounded by the primordium hippocampi and its basal sphere contacts with the cell scanty plane of the zona limitans medialis.

\section{The area precommissuralis.}

In the rostral segment of the forebrain, this area is deffusively arranged with scattered cells and has no definite demarcation with the surroundings. Caudally this area is bordered dorsally by the nucleus medialis septi and the primordium hippocampi, laterally by the striatum and ventrally by the medial extension of the area superficialis basalis. It, however, is not subdivided into two parts of the pars superior and pars inferior. Until the transversal slit of the ventriculus impar is seen, this area occupies nearly the total length of the olfactorius medialis.

\section{The epistriatum.}

From the rostral segment to the middle part of the hemisphere, the anterior part of the epistriatum lies at the lateral wall being intervened between the pallial lobe and the area olfactorius lateralis as the medium-sized cell group. The epistriatum swells medially and ventrally as the scattered cell area. In the caudal tracement, the epistriatum removes somewhat ventromedially and faces to the ventrolateral expansion of the primordium hippocampi having the ventral elongation of the fifth pallial layer between them. On the level where the zona limitans medialis appears, the epistriatum is scarcely seen.

\section{The striatum.}

Ventral to the epistriatum, the striatum begins to appear as the sacttered cell mass. Extending back, this nuclear mass gradually enlarges into a round shape in section, and moreover removes medially to meet its fellow of the opposite side. It finally fuses with the contralateral component above the transversal slit of the ventriculus impar. 
The area superficialis basalis or the tuberculum olfactorius, the nucleus taeniae.

Nearly the total length of the forebrain, this area occupies half of the basal area with the scattered cells. At the anterior segment of the brain, this area is situated at the basal superficial zone and then is bordered laterally by the area olfactorius lateralis. On the level where the nucleus preopticus begins to appear at the midline of the base of the brain, this area gradually reduces its width and makes the laminar layer as nearly like as that of the pallial lobe, such as the superficial cell free zone, the somewhat dense cell lamina and the broad scattered cell lamina.

\section{The nucleus preopticus.}

In the caudal segment of the forebrain,the nucleus preopticus begins to appear as the united nuclear mass which acrosses the ventral midline. More caudally, it is separated left and right having the ventral medial sulcus standing fare to face. Further caudalward, where the transversal slit of the ventriculus impar begins to appear both the nuclei preoptici fuse into a single nuclear mass at the midline. It, however, stretches dorsally and medially beneath the slit of the ventriculus impar.

Fiber connections of the telencephalon.

In the anterior segment of the forebrain, the fibers derived from the fila olfactoria may be genetally classified into the medial and lateral olfactory radiations. The former fibers interpret the pallial lobe and the primordium hippocampi of the homolateral lobe and moreover some of them meet with the contralateral component uncrossed. The majority of the lateral olfactory radiation spreads in the lateral olfactory area and moreover it may have the relation with the entire area of the telencephalon but is unsettled in this specimen. The interconnected fibers among the telencephalic nuclear masses can feebly be seen. From the whole area and especially from the basal sphere of the striatum, numerous myelinated fibers spring out and then are aggregated into the remarked fascicle of the tractus strio-hypothalamicus. To this tract numerous fibers from the area superficialis basalis join.

In the middle segment of the forebrain, the pars dorsalis commissurae anterioris or the decussatio interhemispherica which connect the lateral olfactory area of both sides appear at the dorsomedial portion passing through the primordium hippocampi. The pars ventralis commissurae anterioris which composed of the fibers derived from the tractus olfactorius lateralis, tractus strio-hypothalamicus and from the basal superficial area appear typically just front of the recessus preopticus. The fiber termination in the epistria- 
tum of this commissure can be assumed as shown by Ariëns Kappers. The tractus septocorticalis takes the remarked path way from the pallial lobe to the septal portion with a centripetal course.

In the posterior segment of the forebrain, a little number of fibers of the tractus taeniae dorsalis swing ventromedially along the lateral margin of the transversal slit of the ventriculus impar. Lateral to this curved course of the tractus taeniae the ascending fibers of the tractus palli of Edinger are arranged as the intermittent fiber course. Furthermore, lateral to this tract appears superficially stream the fibers of the tractus olfacto-habenularis The fibers of the latter tract go into the stria medullaris. Few fibers of the tractus olfactomedialis or the tractus septo-habenularis and the fibers from the area superficialis basalis join the stria meduallaris. All of the bundles are myelinated and they interpret in the lateral habenular nucleus of the cell scanty portion.

\section{Bibliography.}

Ariëns Kappers, C. U., Huber, G. C. and Crosby, E. C., 1936. The Comparative Anatomy of the Nervous System of Vertebrates Including Man. New York.

Borschert, Max, 1906. Zur Kenntnis des Zentralnervensystems von Torpedo. Morph. Jahrb., Bd. XXXVI, H. x.

Fritsch, G. T., r892. Weitere Beiträge zur Kenntnis des schwach elektrischen Fische. Arch. Anat. u. Physiol. (Physiol. Abt.).

- 1893. Zur Innetvation der elektrischen Organe in Torpedo, Gymnotus, etc. Arch. f. Anat. u. Physiol. (Physiol. Abt.).

- 1895. Uber das numerische Verhältnis den Ganglienzellen im Lobus electricus der Torpedineen zu ihren peripheren Endorganen. Arch. f. Anat. u. Physiol.

Hatai, S., 19or. Observations on the efferent neurons in the electric lobes of Toxpedo accidentalis. Jour. Comp. Neur., Vol, 20, No. r.

Holm, J.F., 1901. The finer Anatomy of the nervous system of Myxine glatinosa. Morph. Jahrb., Bd. 29.

Jansen, J., 1930. The brain of Myxine glutinosa. Jour. Comp. Neur., Vol. 49, No. 3.

Johnst on, J. B., 190i. The brain of Acipenser. Jena.

Kuhlenbeck, H., r927. Vorlesungen über das Zentralnervensystem der Wirbeltier. Jena,

Mencl, E., 1902. Einige Bemerkungen zux Histologie des elektrischen Lappens bei Torpedo marmorata. Arch. f. mikr. Anat. Bd. 60.

Stuart, C. and Kamp. C. J., 1934- The electric organ and its innervation in Malopterurus electricus. Proceeding. Kon. Acada. v. Wetensch. Amsterdam, Vol. XXXVII, No. 2.

Suzuki, N., 1936. On the lobus electricus and the nervi electrici in Narke japonica. J. Orient. Med. Vol. XXV, No. I.

-1938. On the commissura praeinfundibularis et post-infundibularis in Selachian Brain. Okajimas Fol. Arat. Jap. Bd. XVI, H. 2. 